\title{
QUALIFICATION HURDLES AND CHANCES FOR E-MOBILITY
}

\author{
Matthias Klumpp ${ }^{1}$, Hella Abidi ${ }^{2}$, Torsten Marner ${ }^{3}$ \\ 1,2,3 Institute for Logistics and Service Management, FOM University of Applied Sciences, \\ Leimkugelstraße 6, 45141 Essen, Germany
}

Received 19 May 2014; accepted 8 August 2014

\begin{abstract}
This research contribution aims at describing the crucial role of personnel qualification in logistics as well as in support staff for the use of electric vehicles. The question of "soft process and qualification facts" connected to the use of electric vehicles in the logistics field is explored. Therefore, in a gap analysis based on two empirical studies regarding a comprehensive business knowledge ("Berufswertigkeit") qualification survey in logistics $(2012, n=1.068)$ as well as an AHP expert interview $(2013, n=40)$ specific qualification fields and possible hurdles for the use of electric vehicles in logistics are identified and discussed with the help of further expert survey inputs $(2014, n=181)$. Results show that support processes (recharging, maintenance) as well as planning and driving processes (range estimation and control, security issues) for commercial electric vehicles require more and different competences than traditional diesel-powered trucks; this poses a major strategic challenge for most transport and logistics companies. Further research lines have to identify specific areas of necessary qualification for electric vehicles in logistics as well as specific target groups (drivers, support staff, maintenance and administration). The operational use of electric vehicles in logistics will strongly depend on the answers to the qualification questions addressed in this paper as has been shown also for the basic cost/investment calculation for electric vehicles.
\end{abstract}

Keywords: electric mobility, qualification, investment hurdles, process requirements.

\section{Introduction}

The question of qualification and competences for the logistics sector has gained importance as well as attention in the last two decades (Esper et al., 2007; Mangan and Christopher, 2005; Lancioni et al., 2001; Rao et al., 1998). Within this contribution the authors for the first time test the connection of new research content in the field of electric mobility in logistics with logistics qualification. This could and should lead to a "strategic gap analysis of logistics qualifications" regarding new and evolving topics in logistics. In this sense, the proposed topic here - electric mobility - represents a role model and "proof of concept" regarding the feasibility of "strategic qualification management in advance" for the logistics industry: In the past, research and companies acted in a way according to the "waterfall model", first introducing new technologies and concepts (barcode, "Radio Frequency Identification - RFID” etc.), second adapting their processes to the new technologies and only third (and latest) to adapt/qualify the personnel to the new innovations regarding their competences and qualification e.g. by training with the new equipment as well as processes. This has changed already in

${ }^{1}$ Corresponding author: matthias.klumpp@fom-ild.de 
the last innovation waves (especially with RFID) as it was not feasible to introduce the technology and then change the corporate processes in logistics afterwards: As proven by many research contributions and practical examples (Bioly and Klumpp, 2012; Lee and Chan, 2009), it is only economically viable to invest in RFID technology if processes and especially services and value drivers towards customers are evaluated and changed (i.e. when RFID provides added value beyond adapting to existing processes in order to make them faster/leaner - therefore providing an additional "willingness to pay" from the customer).

This will enhance further as shown in this contribution for the example with the expected change of fleet management and propulsion concepts in logistics (road transport, presumably long-term all modes of transport) as investing in for example electric trucks will not allow for long retraining and qualification periods for all personnel (blue and white collar) after the investment and introduction of the new vehicles due to the value of the investment. Instead, the authors suggest that companies as well as research should evaluate the expected qualification gap regarding their personnel before the planned investment and introduction and also schedule the retraining and qualification measures before the implementation ("Qualification Time to Live Process - QTLP”). This is standard in high-value production supply chains as e.g. in the automotive (new model series training) and electrical engineering industries (Chryssolouris et al., 2013; Kley et al., 2011) - but not yet in the logistics sector.

In order to provide this described "proof of concept" the contribution is structured as follows: The second section will outline the two existing data pools from empirical research regarding logistics qualification and the comprehensive business knowledge ("Berufswertigkeit") concept of qualification measurement (2.1.); section 2.2. will describe the empirical research done in 2013 regarding pending innovation topics connected to electric mobility (in logistics, i.e. last mile distribution) from the company perspective and the operational logistics processes. Section 3 will outline the specific research method used to match the two datasets in order to enable a strategic gap analysis regarding the necessary qualifications for implementing electric mobility in logistics. The following section 4 will therefore outline the gap analysis based on the matching of operational topics as well as qualifications and will discuss the implications and possible measures regarding the identified qualification gaps. Finally, section 5 will provide some conclusions as well as an outlook towards further research regarding the proposed strategic gap analysis in logistics qualification and training.

\section{Theoretical Framework}

\subsection{Comprehensive Business Knowledge Evaluation ("Berufswertigkeit")}

Germany is currently ranked in the Logistics Performance Index Global Ranking in the first place (Worldbank, 2014). The estimated turnover of the German logistics industry is about 222.5 billion Euro (2012), the turnover in 2001 was about 160 billion Euro (Kille and Schwemmer, 2012). The experts from the logistics industry expect an economic growth of $4 \%$ to $5 \%$ per anno (Ehmer and Heymann, 2010). At present, the logistics industry is characterized by economic growth, demographic development, occupational aging structure and a huge lack of specialists. Furthermore, the employees from logistics 
industry are faced with complex logistics structure, innovative technologies, timeliness, flexibility, decreasing cost in the same time achieving high service level and aligning logistics structure as well as processes with sustainability and environment friendly concepts (Klumpp et al., 2013). In 2011, 2.8 million persons were employed in the German logistics sector. Out of that, $29 \%$ work in the transport field, $7 \%$ are responsible for administration, $47 \%$ handle the goods in warehouses and load cargo, $17 \%$ are dealing with indirect activities such as consultant or lawyer or insurance (Kille and Schwemmer, 2012). In total, the logistics industry in Germany has 654,606 employees as office members and 1,988,322 employees are blue collar workers such as truck drivers or warehouse staff (Klaus et al., 2010). In the German logistics industry $30.03 \%$ of all fulltime employees have only an 'unknown' suggestedly non-formal - education, $13.72 \%$ are totally without an education and only $2.78 \%$ of all full time employees possess an university degree. In Germany there are 43 universities, 71 universities of applied sciences

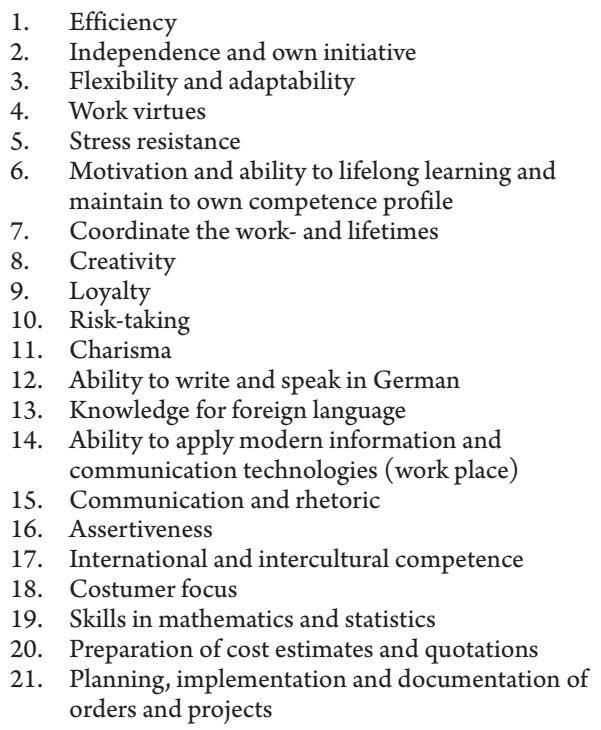

and 14 universities of cooperative education who offer academic training to the employees of the logistics sector (Roth, 2012; Roth and Klaus, 2008; Hildebrand and Roth, 2008). Furthermore, there are continuing education facilities who also allow achieving academic degrees in logistics (Roth, 2010; Roth, 2012). This personnel structure and different education overview of all logistics full-time employees lead to specify and to identify specific areas of necessary qualification for electric vehicles in logistics as well as specific target groups (drivers, support staff, maintenance and administration).

From January 2011 until June 2012 a field survey to evaluate the competence of the employees of the German logistics industry was conducted, based on the Berufswertigkeit measurement concept (Klumpp, 2007; Klumpp and Schaumann, 2007). This includes 36 qualification requirement criteria that represent modern daily work environments which are used to calculate the "Berufswertigkeitsindex" (listed below).

22. Negotiations capacity

23. Analytical problem-oriented work

24. Quality management (optimization of processes and products or service quality)

25. Conceptual and strategic implementation of industry-specific knowledge and experience

26. Identification with the company

27. Strategic orientation, determine/control the complete company

28. Understanding solutions of complex technical problems

29. Basic knowledge of business administration

30. Perception of functions of management and organization

31. Conceptual working in immediate workplace

32. Planning and control procurement and logistics processes

33. Staff requirements and staff mission planning/ staff development

34. Team, staff and leadership

35. Improving responsible care

36. Legal knowledge 
The "Berufswertigkeitsindex" (BWI) is calculated by a summed and unweighted index of individual evaluations of the 36 qualification requirement criteria. The value range of the BWI begins by 0 and ends at 100. The following Fig. 1 represents the calculation in detail. This equation includes a recoding: The achieved average values will be subtracted by the figure five. Hereby, the highest achieved value is the numerical figure 4 und the smallest achieved figure is 0 . The normalized index $100 \%$ can be achieved by the multiplication with the figure 25 .

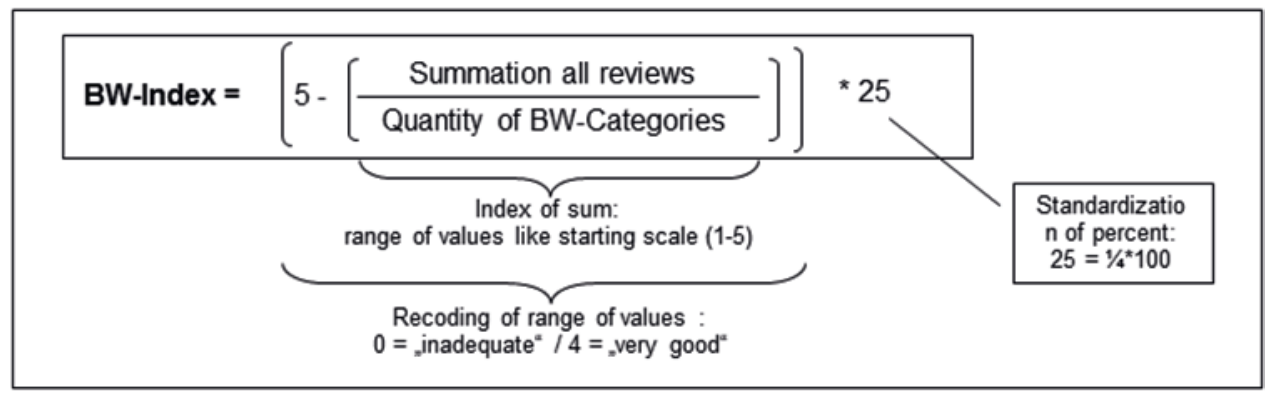

Fig. 1.

Berufswertigkeitsindex Calculation Scheme

Source: Klumpp et al. (2011)

A representative telephone survey in the states of Hessia and North-Rhine Westphalia in Germany determined the competences of 1,068 persons from the German logistics sector. In 2012, 379 female and 689 male persons have contributed to this survey. The respondents represent various professional levels at their current working place: $88.6 \%$ are employed as white collar workers on different levels like branch manager, team leader and office clerk in their company and $11.4 \%$ work in the warehouse or as truck driver, namely blue collar work. A further example shows the investigation of employees who have adapted their knowledge as well as expertise based on learning on the job. These are subcategorized in three groups with the professional knowledge acquired up to $50 \%$, up to $70 \%$ and more than $70 \%$ outside formal education institutions such as schools, vocational schools and universities. Fig. 2 obviously depicts that all three groups have BWI shares at similar levels as the indicated lines are very similar. The figure confirms that those employees from the German logistics sector that have obtained their competences outside the school facilities are largely represented in the logistics sector and provide similar qualifications levels as the people with intensive formal training curricula. 


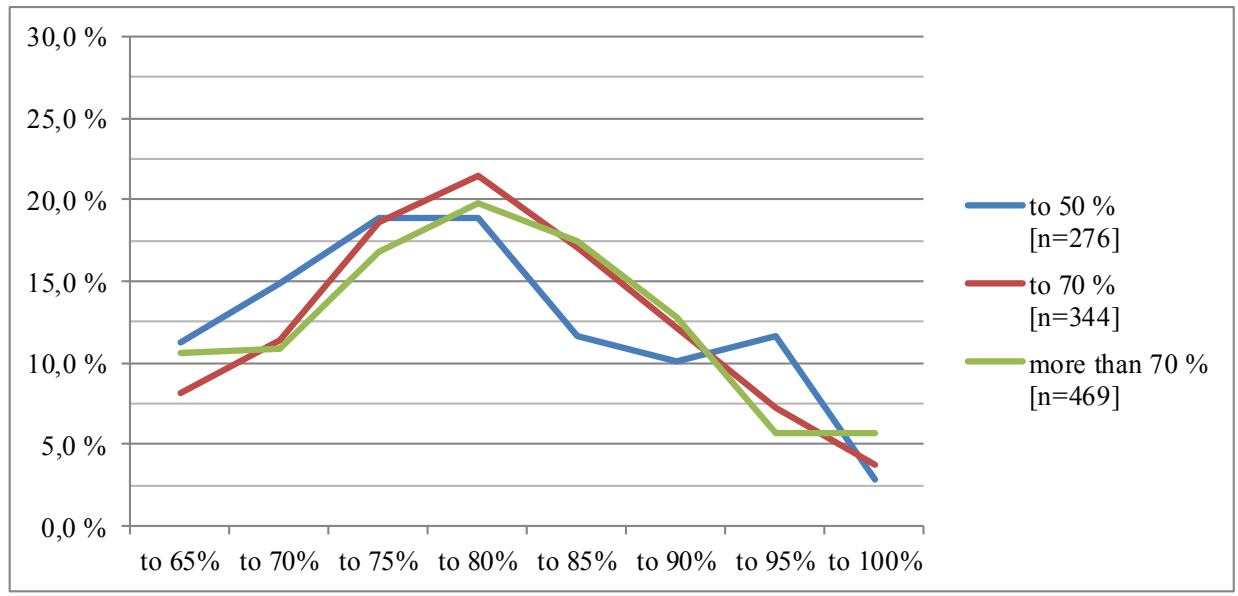

Fig. 2.

Obtained Competences outside Formal Education Facilities: Grouped BWI

The further Fig. 3 below outlines the individual analysis results for a selected few of the total of 36 Berufswertigkeit items (qualification requirements), showing the scale of the average results taken from the German school grade system ( 1 best, 5 worst) with values ranging from 1.7 to 2.3 in this case, the overall range of results reached from 1.2 to 2.5 for the study.

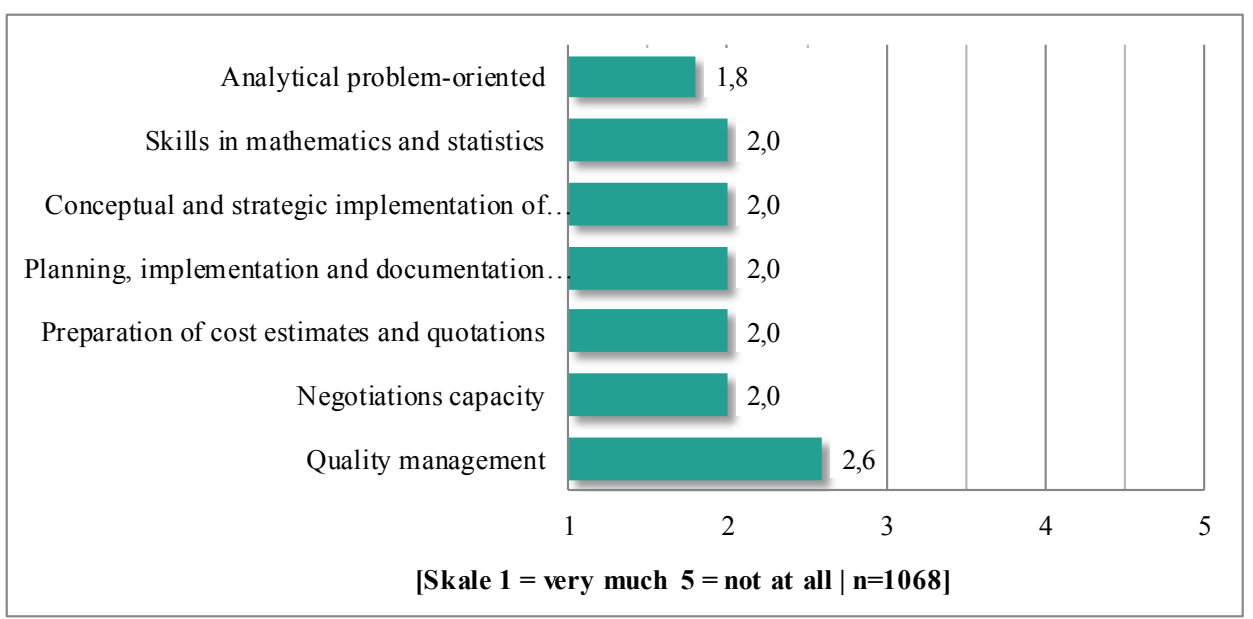

Fig. 3.

Fulfilment of Selected Professional Competences 


\subsection{Analytical Hierarchy Process Survey for Electric Vehicles}

Currently, vehicle fleet investments and modernization is heavily testing alternative propulsion technologies such as gas (LNG), hybrid motors and electric drives. Yet, still a number of challenges prevent a widespread use of electric vehicles (EV) in logistics today. For example the limited maximum range constrains the application fields, so that currently EV are mostly to be used for urban delivery trips ("last mile"). Especially in urban areas, EV show a high potential in terms of an acceptable implementation of electric mobility. According to this, the advantages of the EV are especially the noise-reduced and low emission transport (Katrasnik, 2013; Vastag and Schaumann, 2012). To increase the use of EV, research efforts are driven in many ways, especially in engineering. In this field research is focused for example on the improvement of the battery technology for improving energy supply and increasing the range of the EV. From a business perspective the commercial launch and use of the EV are prohibited by a lack of knowledge as for example investment calculations are hindered by missing information. Because of limited resources it is a challenge - particularly for small and medium-sized enterprises - to calculate the important operational adjustments and business investments necessary for electric mobility (Davis and Figliozzi, 2013; Knop, 2009).

The objective is to investigate only the changes in costs and operational processes caused by the use of EV in lastmile-distribution of logistic and trading companies. The accomplishment is based on a simple-designed and practical investment analysis in terms of a comparative vehicle cost calculation. In the first step of this research the fundamental effects, concerning changes in costs, are shown by a comparison of a conventional diesel-engine vehicle versus an EV. The second step indicates the specific cost changes for an exemplarily selected operational change area by using EV. This knowledge increases the transparency of costs for practitioners who seek an extension or conversion of the own fleet with EV. In the course of first research activities operational change areas were identified and queried in an expert survey with 40 logistics experts in Germany, using the method of the Analytic Hierarchy Process (AHP). The analysis of the results showed that in particular core logistics processes like transportation and scheduling as well as transport goods and fleet management are relevant operational change areas when using EV. The high weighting of the operational change areas transportation and scheduling is caused by the restricted range of $\mathrm{EV}$ which requires an adjustment of the route and tour planning. The reason for the significance of transport goods is the limited payload of EV (Fig. 4).

These evaluated areas of change priority are further taken into account with a matching regarding the displayed Berufswertigkeit criteria from the section above in order to allow for the described qualification-content match regarding the future innovation topic of electric vehicle use in logistics. 


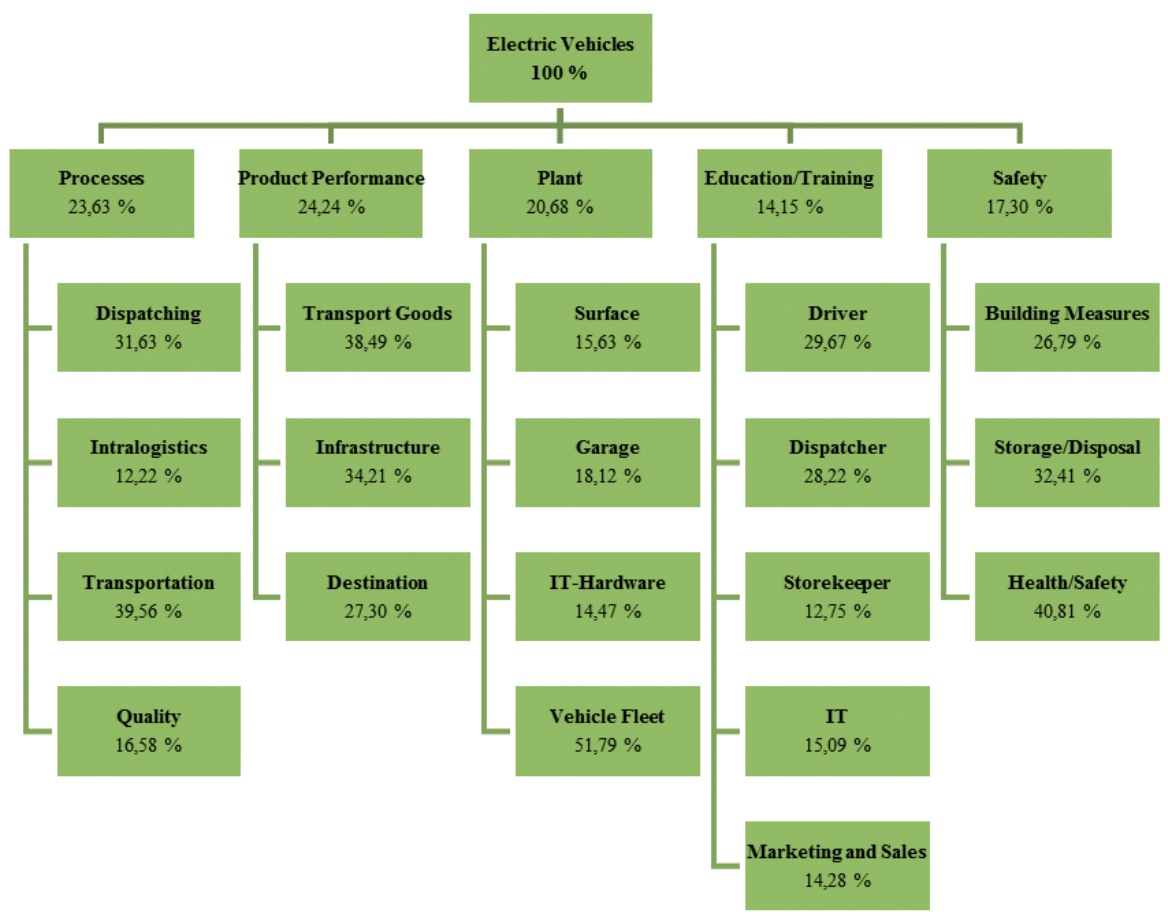

Fig. 4.

Operational Change Areas: Local AHP Weighting

\section{Research Method}

The capability of logistics learning mechanisms depends on four components: temporal components, cultural components, structural components and relational components. The consideration of these four components is a major requirement of a successful learning process. The cultural component can be seen as a basis of learning because the whole logistics sector and nowadays supply chains are internationally oriented. The structural component regards the specifications of the employee's organization to realize learning activities on-the-job: Flexibility in time and position. Relational components assist the collaboration and communication within a strong cross-linked company structure and the temporal component supports the velocity of changes within the logistics sector and synchronizes them with the learning process (Esper et al., 2007). The goal of learning is to match employee's knowledge with the needs of the logistics industry. The needs can be displayed as the shape of a ' $\mathrm{T}$ ' (Fig. 5): The horizontal level displays specific logistics know-how and the vertical level displays the understanding of other company departments with connection to logistics, for example process management, engineering or controlling. In best case situations, operative labour with practical experience has to be equipped with management tools and techniques and developed for logistics managers of the future. 


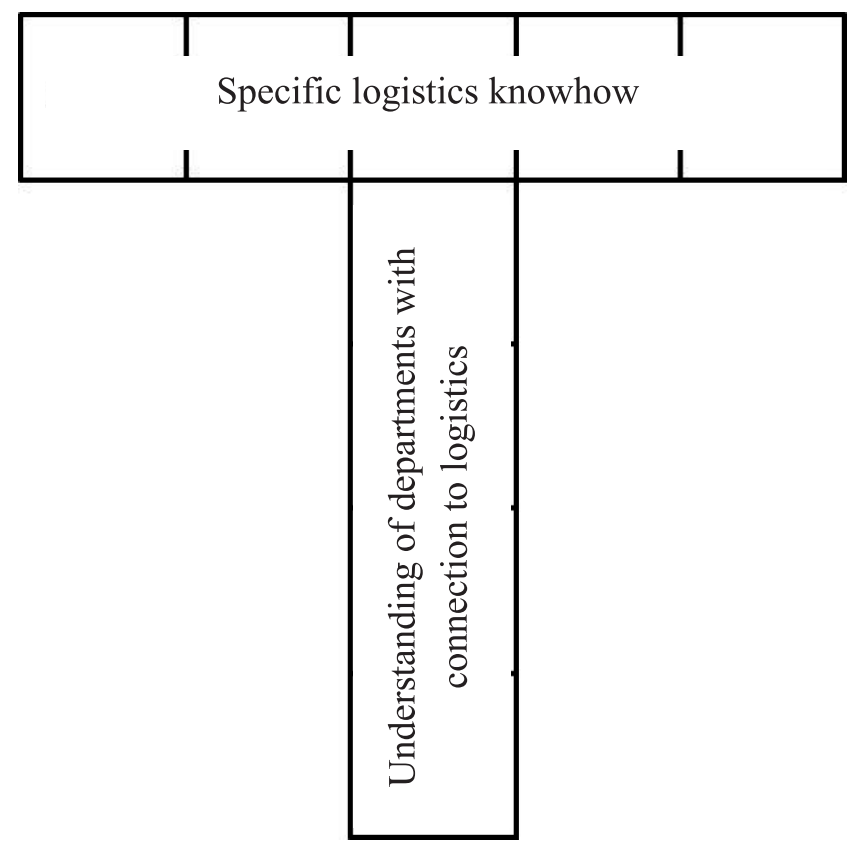

Fig. 5.

Employees' Capabilities of Logistics Industry

Source: Mangan and Christopher (2005)

To achieve the relevant data we started an empirical approach and designed a questionnaire that consists of two parts. The first part of the questionnaire described the 36 Berufswertigkeit criteria (section 2.1), the second part of the questionnaire indicated the specific tasks from the AHP expert interview (section 2.2) which illustrate the specific activities when an electric vehicle is implemented into logistics processes. The task to the respondents was to match 36 Berufswertigkeit criteria with the different specific tasks that are necessary to manage the implementation of electric vehicles in the logistics industry. We addressed the questionnaire to students from the FOM University of Applied Sciences. The students at the FOM University of Applied Sciences are part-time. The programs at FOM University ${ }^{2}$ are addressed to businesspeople who would like to continue higher education without leaving the job. The questionnaire was only addressed to students from business administration study programs. The aim was not only to consider the logistics industry in our research but even thought to get a general view. We have to take into account that the implementation of electric vehicles is not a future task that only the logistics sector is faced with. In the

\footnotetext{
${ }^{2}$ FOM University of Applied Sciences is a private university and was founded in 1993. Currently 24.500 people are studying business administration as well as engineering science. FOM University of Applied Sciences offers bachelor and master programs.
} 
end of the questionnaire the participants were asked to include their business title as well as the business experience in years and their gender. Altogether 181 persons from different business companies in Germany participated in the survey. These persons largely represent the industry and logistics service sector in Germany. In the sample, $41 \%$ female and $49 \%$ male persons estimated the matching of Berufswertigkeit criteria to the specific tasks from AHP expert interview (10\% not answered). The majority of the respondents ( 79 persons) have business experience between three and six years followed by persons who are working for three years (43 persons). About 36 persons are working in their companies for 6 years and more (Fig. 6).

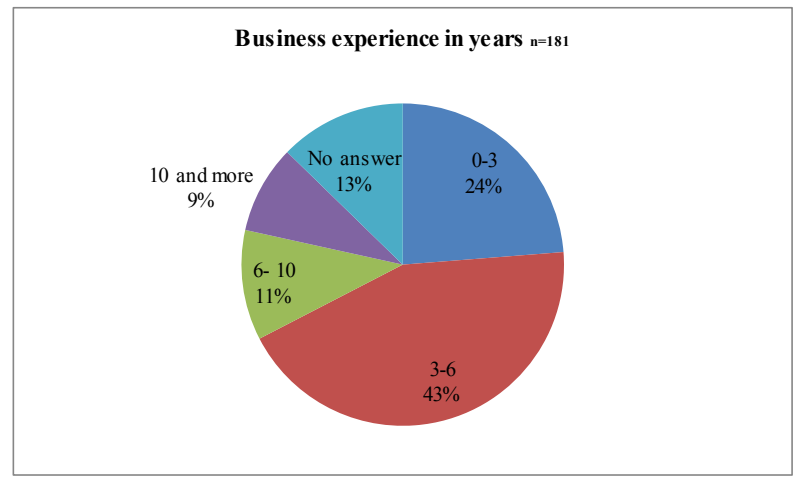

Fig. 6.

Business Experience of the Respondents in Years

The results of the survey are included in the following Table 1 with the full matrix matching of all AHP survey criteria (left side, lines) with all the 36 Berufswertigkeit criteria (right side, columns headings). The first field of the table therefore indicates that 24 out of 181 respondents evaluated the Berufswertigkeit qualification criterion "analytical problemoriented work" as a content match towards the AHP change area evaluation for electric mobility "operational equipment". The numbers are marked in bold for all values above the threshold of 21 as this was the lowest number achieved for any one AHP change area evaluation criterion ("product performance/destination"). Additionally the highest number of nominations per line (AHP criterion) is marked in bold italic numbers.
In a second evaluation step, all marked matches (above 21 nominations) were individually matched with a subtraction of their AHP and BW values as follows. The original AHP values (per cent of the total AHP nominations, maximum value 10.71 and minimum value 1.80 ) were normalized according to the following algorithm in order to receive the same scale as the existing BW values (maximum 1.21, minimum 2.57): Subtracting the AHP value divided by 7 from the number 2.75 in order to receive the normalized AHP value (new range 1.22 to 2.49). The difference between AHP normalized values and BW values was indicated green for values above 0.15 , yellow for values between 0.15 and -0.15 and red ("gap") for values below -0.15 (Table 1). 


\section{Table 1}

Results of Matched Competences to Specific Tasks

\begin{tabular}{|c|c|c|c|c|c|c|c|c|c|c|c|c|c|c|c|c|c|c|c|}
\hline Competence FieldS & $\begin{array}{l}\text { I } \\
\frac{1}{8} \\
\frac{1}{2}\end{array}$ & 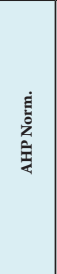 & 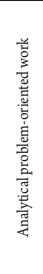 & 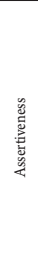 & 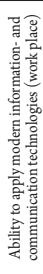 & 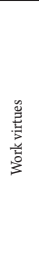 & 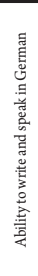 & 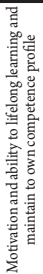 & 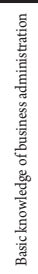 & $\begin{array}{l}\text { 总 } \\
\text { 炰 }\end{array}$ & 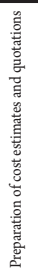 & 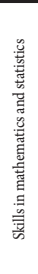 & 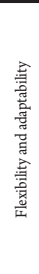 & 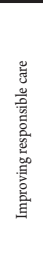 & 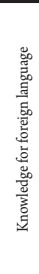 & 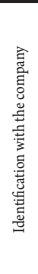 & 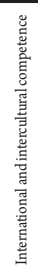 & 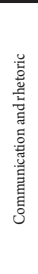 & 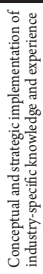 \\
\hline BW VALUE & & & 1,85 & 1,72 & 1,79 & 1,33 & 1,21 & 1,67 & 2,41 & 1,96 & 1,98 & 1,99 & 1,46 & 2,65 & 2,11 & 1,31 & 2,35 & 1,94 & 2,01 \\
\hline $\begin{array}{l}\text { Operational equipment/ operational area } \\
\text { (utility space, ramp, charging station) }\end{array}$ & 3,23 & 2,289 & 24 & 3 & 13 & 5 & 18 & 5 & 35 & 0 & 11 & 20 & 16 & 4 & 2 & 6 & 2 & 3 & 15 \\
\hline $\begin{array}{c}\text { Operational equipment/ vehicle fleet } \\
\text { (number and composition of vehicle fleet) }\end{array}$ & 10,71 & 1,220 & 15 & 3 & 9 & 5 & 14 & 5 & 55 & 1 & 23 & 27 & 15 & 3 & 2 & 8 & 3 & 3 & 16 \\
\hline Operational equipment/ IT-Hardware & 2,99 & 2,323 & 26 & 3 & 80 & 3 & 10 & 17 & 25 & 1 & 9 & 23 & 14 & 1 & 12 & 2 & 2 & 0 & 15 \\
\hline Operational equipment/workshop & 3,75 & 2,214 & 15 & 3 & 6 & 16 & 11 & 4 & 25 & 1 & 15 & 6 & 15 & 9 & 3 & 3 & 1 & 3 & 17 \\
\hline Logistic processes/ transport planning & 7,47 & 1,683 & 57 & 15 & 28 & 8 & 39 & 7 & 51 & 6 & 38 & 33 & 32 & 3 & 24 & 5 & 9 & 10 & 15 \\
\hline $\begin{array}{c}\text { Logistic processes/ stock (overturn, storage, } \\
\text { commission) }\end{array}$ & 2,89 & 2,337 & 26 & 4 & 15 & 9 & 24 & 6 & 43 & 2 & 23 & 35 & 13 & 5 & 7 & 7 & 4 & 2 & 14 \\
\hline Logistic processes/ quality & 3,92 & 2,190 & 40 & 12 & 16 & 16 & 21 & 19 & 45 & 2 & 6 & 10 & 10 & 9 & 9 & 12 & 4 & 2 & 18 \\
\hline Logistic processes/transport & 9,35 & 1,414 & 34 & 9 & 18 & 8 & 16 & 9 & 30 & 2 & 12 & 17 & 30 & 8 & 29 & 6 & 13 & 6 & 20 \\
\hline $\begin{array}{c}\text { Product performance/ infrastructure (route } \\
\text { profile) }\end{array}$ & 8,29 & 1,566 & 24 & 5 & 10 & 5 & 12 & 7 & 29 & 1 & 14 & 37 & 17 & 5 & 4 & 4 & 8 & 0 & 24 \\
\hline $\begin{array}{l}\text { Product performance/ transport goods } \\
\text { (bulky, hazardous goods) }\end{array}$ & 9,33 & 1,417 & 20 & 6 & 4 & 6 & 9 & 4 & 17 & 1 & 8 & 8 & 17 & 16 & 7 & 5 & 3 & 3 & 18 \\
\hline $\begin{array}{c}\text { Product performance/ destination (loading } \\
\text { and unloading) }\end{array}$ & 6,62 & 1,804 & 11 & 5 & 4 & 6 & 14 & 8 & 14 & 3 & 8 & 7 & 16 & 6 & 7 & 3 & 6 & 6 & 21 \\
\hline $\begin{array}{l}\text { Safety/ labor protection (standardization, } \\
\text { certifications) }\end{array}$ & 7,06 & 1,741 & 5 & 9 & 7 & 20 & 27 & 26 & 17 & 2 & 2 & 7 & 2 & 31 & 2 & 4 & 3 & 3 & 15 \\
\hline Safety/ construction (explosion protection) & 4,64 & 2,087 & 14 & 7 & 6 & 15 & 16 & 15 & 8 & 4 & 2 & 7 & 5 & 31 & 1 & 2 & 0 & 7 & 27 \\
\hline $\begin{array}{c}\text { Safety/ storage and disposure (old batteries, } \\
\text { used parts) }\end{array}$ & 5,61 & 1,949 & 11 & 6 & 2 & 13 & 13 & 13 & 9 & 1 & 3 & 3 & 3 & 43 & 2 & 2 & 3 & 4 & 22 \\
\hline $\begin{array}{l}\text { Further training measures/ transport } \\
\text { planning) }\end{array}$ & 3,99 & 2,180 & 15 & 11 & 15 & 11 & 30 & 68 & 25 & 11 & 5 & 13 & 17 & 16 & 16 & 3 & 10 & 15 & 6 \\
\hline $\begin{array}{l}\text { Further training measures/ fleet personal } \\
\text { (manner of driving, safety) }\end{array}$ & 4,2 & 2,150 & 6 & 7 & 9 & 14 & 22 & 70 & 16 & 7 & 0 & 6 & 17 & 32 & 10 & 8 & 7 & 21 & 6 \\
\hline $\begin{array}{l}\text { Further training measures/ IT (new software, } \\
\text { maintenance) }\end{array}$ & 2,14 & 2,444 & 10 & 3 & 43 & 9 & 30 & 80 & 15 & 4 & 6 & 9 & 21 & 8 & 9 & 4 & 3 & 12 & 6 \\
\hline $\begin{array}{c}\text { Further training measures/ stock loading and } \\
\text { unloading, handling) }\end{array}$ & 1,8 & 2,493 & 5 & 3 & 9 & 10 & 26 & 67 & 16 & 6 & 0 & 6 & 18 & 16 & 6 & 7 & 3 & 13 & 6 \\
\hline $\begin{array}{l}\text { Further training measures/ marketing and } \\
\text { distribution (strategies of marketing) }\end{array}$ & 2,02 & 2,461 & 12 & 21 & 20 & 9 & 48 & 75 & 40 & 43 & 24 & 17 & 16 & 9 & 19 & 29 & 10 & 37 & 9 \\
\hline
\end{tabular}




\begin{tabular}{|c|c|c|c|c|c|c|c|c|c|c|c|c|c|c|c|c|c|c|c|}
\hline Competence FieldS & 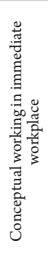 & $\begin{array}{l}\text { 袬 } \\
\text { 苞 }\end{array}$ & 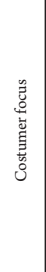 & 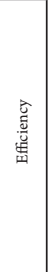 & 急 & 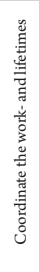 & 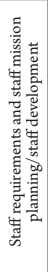 & 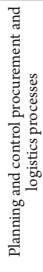 & 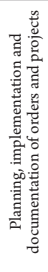 & 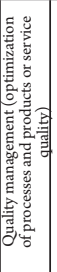 & 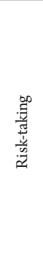 & 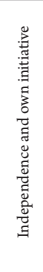 & 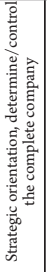 & 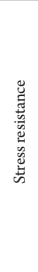 & 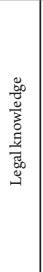 & 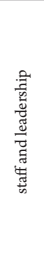 & 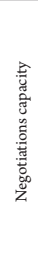 & 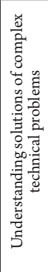 & 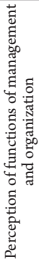 \\
\hline BWVALUE & 1,91 & 2,02 & 2,00 & 1,36 & 1,21 & 1,92 & 1,95 & 2,07 & 1,98 & 2,57 & 1,63 & 1,37 & 2,17 & 1,64 & 2,31 & 1,92 & 2,01 & 2,21 & 2,24 \\
\hline $\begin{array}{l}\text { Operational equipment/ operational area } \\
\text { (utility space, ramp, charging station) }\end{array}$ & 14 & 12 & 9 & 17 & 1 & 3 & 2 & 38 & 10 & 11 & 2 & 4 & 10 & 7 & 14 & 2 & 5 & 18 & 23 \\
\hline $\begin{array}{c}\text { Operational equipment/ vehicle fleet } \\
\text { (number and composition of vehicle fleet) }\end{array}$ & 7 & 2 & 8 & 16 & 1 & 2 & 12 & 35 & 9 & 6 & 3 & 7 & 6 & 5 & 6 & 4 & 9 & 3 & 8 \\
\hline Operational equipment/ IT-Hardware & 6 & 5 & 3 & 15 & 3 & 4 & 3 & 8 & 17 & 12 & 1 & 6 & 5 & 3 & 5 & 3 & 5 & 53 & 9 \\
\hline Operational equipment/ workshop & 11 & 11 & 7 & 13 & 4 & 3 & 12 & 6 & 5 & 13 & 2 & 4 & 7 & 5 & 9 & 8 & 2 & 18 & 11 \\
\hline Logistic processes/transport planning & 6 & 11 & 32 & 15 & 4 & 3 & 14 & 33 & 45 & 12 & 1 & 17 & 4 & 24 & 5 & 4 & 9 & 6 & 7 \\
\hline $\begin{array}{l}\text { Logistic processes/ stock (overturn, storage, } \\
\text { commission) }\end{array}$ & 9 & 6 & 11 & 18 & 4 & 4 & 9 & 38 & 21 & 19 & 2 & 6 & 6 & 15 & 9 & 6 & 3 & 4 & 6 \\
\hline Logistic processes/ quality & 7 & 3 & 30 & 15 & 4 & 6 & 4 & 22 & 18 & 89 & 3 & 8 & 4 & 10 & 9 & 3 & 4 & 12 & 6 \\
\hline Logistic processes/ transport & 5 & 4 & 28 & 17 & 4 & 14 & 6 & 41 & 18 & 22 & 9 & 8 & 3 & 20 & 15 & 3 & 7 & 6 & 4 \\
\hline $\begin{array}{c}\text { Product performance/ infrastructure (route } \\
\text { profile) }\end{array}$ & 3 & 7 & 10 & 20 & 0 & 5 & 0 & 15 & 14 & 10 & 6 & 5 & 4 & 5 & 7 & 5 & 4 & 9 & 4 \\
\hline $\begin{array}{l}\text { Product performance/ transport goods } \\
\text { (bulky, hazardous goods) }\end{array}$ & 9 & 10 & 7 & 25 & 1 & 6 & 3 & 18 & 13 & 16 & 25 & 2 & 2 & 9 & 24 & 2 & 2 & 13 & 2 \\
\hline $\begin{array}{l}\text { Product performance/ destination (loading } \\
\text { and unloading) }\end{array}$ & 7 & 7 & 11 & 13 & 3 & 4 & 2 & 16 & 9 & 14 & 5 & 8 & 4 & 17 & 18 & 3 & 7 & 9 & 2 \\
\hline $\begin{array}{l}\text { Safety/ labor protection (standardization, } \\
\text { certifications) }\end{array}$ & 5 & 1 & 2 & 13 & 3 & 3 & 5 & 1 & 3 & 24 & 9 & 6 & 1 & 5 & 56 & 9 & 4 & 8 & 7 \\
\hline Safety/ construction (explosion protection) & 6 & 3 & 0 & 4 & 5 & 4 & 1 & 2 & 7 & 14 & 17 & 6 & 6 & 3 & 46 & 6 & 0 & 21 & 5 \\
\hline $\begin{array}{c}\text { Safety/ storage and disposure (old batteries, } \\
\text { used parts) }\end{array}$ & 7 & 3 & 1 & 5 & 7 & 6 & 3 & 4 & 2 & 15 & 8 & 11 & 2 & 3 & 51 & 2 & 2 & 4 & 6 \\
\hline $\begin{array}{l}\text { Further training measures/ transport } \\
\text { planning) }\end{array}$ & 4 & 9 & 13 & 12 & 6 & 12 & 25 & 10 & 11 & 13 & 3 & 12 & 3 & 15 & 8 & 10 & 3 & 3 & 1 \\
\hline $\begin{array}{l}\text { Further training measures/ fleet personal } \\
\text { (manner of driving, safety) }\end{array}$ & 3 & 9 & 6 & 17 & 6 & 9 & 22 & 2 & 0 & 8 & 6 & 16 & 2 & 19 & 16 & 16 & 3 & 4 & 3 \\
\hline $\begin{array}{l}\text { Further training measures/ IT (new software, } \\
\text { maintenance) }\end{array}$ & 4 & 8 & 5 & 21 & 4 & 4 & 18 & 1 & 0 & 12 & 3 & 16 & 3 & 9 & 3 & 9 & 2 & 25 & 4 \\
\hline $\begin{array}{l}\text { Further training measures/ stock loading and } \\
\text { unloading, handling) }\end{array}$ & 5 & 14 & 7 & 15 & 1 & 10 & 15 & 8 & 2 & 10 & 3 & 20 & 1 & 16 & 9 & 15 & 1 & 5 & 5 \\
\hline $\begin{array}{l}\text { Further training measures / marketing and } \\
\text { distribution (strategies of marketing) }\end{array}$ & 3 & 25 & 46 & 13 & 5 & 8 & 15 & 2 & 1 & 14 & 6 & 14 & 15 & 8 & 5 & 17 & 25 & 3 & 8 \\
\hline
\end{tabular}




\section{Gap Analysis and Discussion}

In order to examine the need for qualification regarding electric mobility in logistics we provide an additional detailed gap analysis. In this analysis we focus on the 19 specific tasks of electric mobility in logistics that are provided by the AHP analysis criteria and their indicated single most relevant competence field from our survey as described above (e.g. regarding the first listed AHP criterion in Table 1 "Operational equipment/ operational area" there were 38 nominations for the Berufswertigkeit qualification item "Planning and control procurement and logistics processes" which is listed here as No. 7 with a difference of 0.214 by subtracting the BW value of 2.075 from the AHP normalized value of 2.289). Table 2 documents the matches that are used for the gap analysis.

Table 2

Matching and Gap Analysis (Examples)

\begin{tabular}{|c|c|c|c|}
\hline $\begin{array}{l}\text { Number } \\
\text { (corresponds } \\
\text { to figure 4.1) }\end{array}$ & $\begin{array}{l}\text { Specific Task (AHP Electric } \\
\text { Vehicle Process Changes) }\end{array}$ & $\begin{array}{l}\text { Competence Field } \\
\text { ("Berufswertigkeit") }\end{array}$ & $\begin{array}{c}\text { Difference } \\
\text { between AHP } \\
\text { value and BW } \\
\text { value } \\
\end{array}$ \\
\hline 1 & $\begin{array}{l}\text { Further training measures/ } \\
\text { stock loading and unloading }\end{array}$ & $\begin{array}{l}\text { Motivation and ability to lifelong } \\
\text { learning and maintain to own } \\
\text { competence profile }\end{array}$ & 0.819 \\
\hline 2 & $\begin{array}{l}\text { Further training measures/ } \\
\text { marketing and distribution }\end{array}$ & $\begin{array}{l}\text { Motivation and ability to lifelong } \\
\text { learning and maintain to own } \\
\text { competence profile }\end{array}$ & 0.788 \\
\hline 3 & Further training measures/ IT & $\begin{array}{l}\text { Motivation and ability to lifelong } \\
\text { learning and maintain to own } \\
\text { competence profile }\end{array}$ & 0.770 \\
\hline 4 & $\begin{array}{l}\text { Operational equipment/ IT- } \\
\text { Hardware }\end{array}$ & $\begin{array}{l}\text { Ability to apply modern } \\
\text { information- and communication } \\
\text { technologies (work place) }\end{array}$ & 0.532 \\
\hline 5 & $\begin{array}{l}\text { Further training measures/ } \\
\text { disponents }\end{array}$ & $\begin{array}{l}\text { Motivation and ability to lifelong } \\
\text { learning and maintain to own } \\
\text { competence profile }\end{array}$ & 0.506 \\
\hline 6 & $\begin{array}{l}\text { Further training measures/ fleet } \\
\text { personal }\end{array}$ & $\begin{array}{l}\text { Motivation and ability to lifelong } \\
\text { learning and maintain to own } \\
\text { competence profile }\end{array}$ & 0.476 \\
\hline 7 & $\begin{array}{c}\text { Operational equipment/ } \\
\text { operational area }\end{array}$ & $\begin{array}{l}\text { Planning and control procurement } \\
\text { and logistics processes }\end{array}$ & 0.214 \\
\hline 8 & $\begin{array}{l}\text { Product performance/ transport } \\
\text { goods }\end{array}$ & Efficiency & 0.062 \\
\hline 9 & Logistic processes/ stock & $\begin{array}{l}\text { Basic knowledge of business } \\
\text { administration }\end{array}$ & -0.069 \\
\hline 10 & Logistic processes/ disposition & Analytical problem-oriented work & -0.159 \\
\hline 11 & $\begin{array}{c}\text { Operational equipment/ } \\
\text { workshop }\end{array}$ & $\begin{array}{c}\text { Basic knowledge of business } \\
\text { administration }\end{array}$ & -0.192 \\
\hline 12 & $\begin{array}{c}\text { Product performance/ } \\
\text { destination }\end{array}$ & $\begin{array}{c}\text { Conceptual and strategic } \\
\text { implementation of industry- } \\
\text { specific knowledge and experience }\end{array}$ & -0.202 \\
\hline 13 & Safety/ construction measures & Legal knowledge & -0.227 \\
\hline 14 & Safety/ storage and disposure & Legal knowledge & -0.366 \\
\hline 15 & Logistic processes/ quality & $\begin{array}{c}\text { Quality management (optimization } \\
\text { of processes and products or } \\
\text { service quality) }\end{array}$ & -0.384 \\
\hline 16 & $\begin{array}{c}\text { Product performance/ } \\
\text { infrastructure }\end{array}$ & Skills in mathematics and statistics & -0.425 \\
\hline 17 & Safety/labour protection & Legal knowledge & -0.573 \\
\hline 18 & Logistic processes/ transport & $\begin{array}{l}\text { Planning and control procurement } \\
\text { and logistics processes }\end{array}$ & -0.660 \\
\hline 19 & $\begin{array}{l}\text { Operational equipment/ vehicle } \\
\text { fleet }\end{array}$ & $\begin{array}{l}\text { Basic knowledge of business } \\
\text { administration }\end{array}$ & -1.186 \\
\hline
\end{tabular}


The analysis shows the gap between the requirements of the specific tasks of electric mobility in logistics that have been laid down by experts and the fulfillment of skills requirements in logistics as provided by a representative sample of logistics employees in Germany in the 2012 Berufswertigkeit survey. The higher the difference between the normalized Analytic Hierarchy Process value (AHP value) and the Berufswertigkeit value ( $B W$ value) the higher the need for qualification concerning this aspect ("qualification gap"). The following Fig. 6 illustrates the regarded gaps. The matches of the two aspects are sorted by the difference of the normalized AHP value and the BW value.

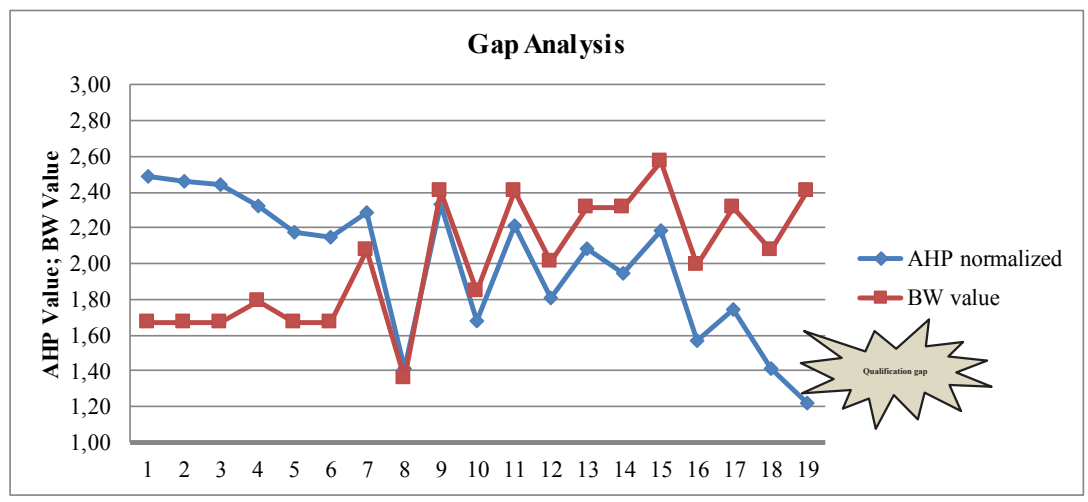

Fig. 7.

Gap Analysis of the Selected Qualification Matches

Fig. 7 and Table 2 show that concerning the matches 1 to 8 , the AHP value is higher than the $\mathrm{BW}$ value. Hence, there is no further need for qualification since the perceived level of qualification that is figured by the "Berufswertigkeitsindex" is higher than the normalized AHP values that symbolize the requirements. However, in the matches 9 to 19 there is a need for further qualification, since in these cases the BW values exceed the normalized AHP values. This is especially true for basic knowledge of business administration, that is considered as most important competence field for the task of vehicle fleet, planning and control procurement and logistics processes that is considered as most important for transport and legal knowledge in connection with labor safety and protection.
To discuss further options, several items of high interest can be selected and outlined as follows:

- $\quad$ [Item 14]: The required safety regulations for storage and disposure of e.g. batteries with electric vehicles has a comparably high priority due to the nature of the relevant materials ("dangerous goods"/potentially environmentally harmful); compared to that the existing qualification levels regarding relevant legal knowledge/regulations information is not so well distributed - therefore a gap can be identified that can be filled by e.g. company or safety training, measures possibly in combination with existing trainings e.g. by chambers of commerce or the safety/ 
quality agencies (“TÜV”) for standard dangerous goods certifications.

- [Item 15]: Similarly the identified qualification gap regarding logistics processes and process quality can possibly easily be mitigated by the inclusion of specific information and training measures regarding electric mobility into standard quality management presentations and trainings for blue and white collar workers in logistics.

- [Item 18]: The second to most important (large) gap identified in this data analysis represents the question of logistics transport processes (AHP) versus the knowledge existing regarding planning and control of logistics and procurement processes; this can be discussed as the one major topic and gap to be addressed directly by specified measures regarding "logistics processes within electric vehicle use in transport" - as no specific existing areas could be identified with easy to use transfer material and trainings. But the calculated gap represents a major obstacle to the implementation of electric vehicles in logistics and should therefore be addressed with the required emphasis.

- [Item 19]: The largest gap was identified for the match of "operational equipment/vehicle fleet” (AHP) with comprehensive business knowledge (Berufswertigkeit) - in this case it can be assumed that basic calculations like for example an investment analysis (also indicated as a huge barrier in other research results e.g. Davis and Figliozzi, 2013) are not feasible today as (a) the required management knowledge is missing with most of the operational employees and (b) the required standardized and historical datasets for such a calculation are still missing for electric vehicles (e.g. depreciation values). Therefore this is presumably the single most important hurdle to electric mobility implementation in logistics, especially with smaller companies typical in the logistics sector.

\section{Conclusions}

This research contribution connects the aspects of personnel logistics qualifications and electric mobility in logistics. We combine the concept of "Berufswertigkeit" and the results of an AHP survey that provides the relevance of specific aspects of electric mobility in logistics to determine the need for qualification in certain areas.

Using the results of a questionnaire ( $n=$ 181 ), we assign the 36 competence fields of the "Berufswertigkeitsindex" to the 19 specific tasks of electric mobility that are provided by an actual AHP analysis of relevant aspects of electric mobility. In a gap analysis we examine the regarded tasks of electric mobility in combination with the competence fields that were found relevant with the help of the results of the questionnaire. A comparison of the normalized $\mathrm{AHP}$ values with the $\mathrm{BW}$ values of the matched aspects shows potential qualification gaps. The higher the differences of the normalized AHP and BW values the higher the qualification gap and therefore the need for further qualification measures.

However, there is a need for further research in this field, especially concerning the testing of the identified qualifications gaps for the specific field of electric mobility implementation in logistics. Furthermore, the general proposal of such a gap analysis 
should be transferred and tested also for further topics in logistics innovations such as e.g. GPS implementation or industry 4.0 applications.

\section{Acknowledgements}

The research results presented are connected to the research project "E-Route", supported by the state of North-Rhine Westphalia and the EU ERDF ("Ziel 2") and are also associated with the BMBF Cluster EffizienzCluster LogistikRuhr (www. effiziencluster.de).

\section{References}

Bioly, S.; Klumpp, M. 2012. RFID Further Education Handbook [Weiterbildungshandbuch RFID]. Logos, Berlin.

Chryssolouris, G.; Mavrikios, D; Mourtzis, D. 2013. Manufacturing Systems: Skills \& Competencies for the Future, Procedia CIRP.DOI: http://dx.doi.org/10.1016/j. procir.2013.05.004, 7(2013): 17-24.

Davis, B.A.; Figliozzi, M.A. 2013. A methodology to evaluate the competitiveness of electric delivery trucks, Transportation Research Part E: Logistics and Transportation Review. DOI: http://dx.doi.org/10.1016/j. tre.2012.07.003, 49(1): 8-23.

Ehmer, P.; Heymann, E. 2010. German Logistics Industry on Growth Path [Deutsche Logistikbranche zurück auf Wachstumskurs]. Deutsche Bank Research - Research Briefing Wirtschaft \& Politik from 19. November 2010, Frankfurt.

Esper, T.; Fugate, B.; Davis-Sramek, B. 2007. Logistics Learning Capability: Sustaining the Competitive Advantage Gained through Logistics Leverage, Journal of Business Logistics. DOI: http://dx.doi. org/10.1002/j.2158-1592.2007.tb00058.x, 28(2): 57-82.
Hildebrand, W.-C.; Roth, A. 2008. Leadership Personnel for Logistics [Führungskräfte für die Logistik - Akademische Ausbildung in Deutschland]. In Baumgarten, H. (ed.). The Best of Logistics - Innovations, Strategies, Implementations [Das Beste der Logistik. Innovationen, Strategien, Umsetzungen]. Berlin, Heidelberg.

Katrasnik, T. 2013. Impact of vehicle propulsion electrification on Well-to-Wheel $\mathrm{CO}_{2}$ emissions of a medium duty truck, Applied Energy. DOI: http://dx.doi. org/10.1016/j.apenergy.2013.03.029, 108(2013): 236-247.

Kille, C.; Schwemmer, M. 2012. German TOP 100 in Logistics - Market Sizes, Shares and Leaders 2012/13 [Die Top 100 der Logistik - Marktgröße, Marktsegmente, und Marktführer in der Logistikdienstleistungswirtschaft 2012/2013]. Hamburg.

Klaus, P.; Hartmann, E.; Kille, C. 2010. German TOP 100 in Logistics - Market Sizes, Shares and Leaders 2011/12 [Die Top 100 der Logistik - Marktgröße, Marktsegmente, und Marktführer in der Logistikdienstleistungswirtschaft 2010/2011]. Hamburg.

Kley, F.; Lerch, C; Dallinger, D. 2011. New Business Models for Electric Cars - a Holistic Approach, Energy Policy. DOI: http://dx.doi.org/10.1016/j. enpol.2011.03.036, 39(6): 3392-3403.

Klumpp, M. 2007. Definition and Concept Berufswertigkeit [Begriff und Konzept Berufswertigkeit]. Arbeitspapiere der FOM Hochschule für Oekonomie \& Management No. 5, 07/2007, Essen.

Klumpp, M.; Schaumann, U. 2007. Requirements for Leadership Personnel and the Concept Berufswertigkeit, Kölner Blätter für Wirtschaftspädagogik, 12: 3-50.

Klumpp, M.; Dilger, B.; Kriebel, K.; Diart, M. 2011. Studie $\gg$ Berufswertigkeit konkret« - Vergleich der Berufswertigkeit spezifischer beruflicher Weiterbildungsabschlüsse und hochschulischer Abschlüsse, Abschlussbericht. Eul: Paderborn. 
Klumpp, M.; Clausen, U.; ten Hompel, M. 2013. Logistics Research and the Logistics World of 2050. In Clausen, U.; ten Hompel, M.; Klumpp, M. (eds.). Efficiency in Logistics, Lecture Notes in Logistics, Springer, Heidelberg, 1-6.

Knop, R. 2009. Success Factors for SMEs - A Guide for IT and Cooperation [Erfolgsfaktoren strategischer Netzwerke kleiner und mittlerer Unternehmen - Ein IT-gestützter Wegweiser zum Kooperationserfolg]. Gabler, Wiesbaden.

Lancioni, R.; Forman, H.; Smith, M.F. 2001. Logistics and supply chain education: Roadblocks and challenges, International Journal of Physical Distribution \& Logistics Management. DOI: http://dx.doi.org/10.1108/ EUM0000000006287, 31(10): 733-745.

Lee, C.K.M.; Chan, T.M. 2009. Development of RFID-based Reverse Logistics System, Expert Systems with Applications. DOI: http://dx.doi.org/10.1016/j. eswa.2008.12.002, 36(5): 9299-9307.

Mangan, J.; Christopher, M. 2005. Management Development and the Supply Chain Manager of the Future, International Journal of Logistics Management, 16(2): 178-191.
Rao, K.; Stenger, A.J.; Wu, H.-J. 1998. Integrating the Use of Computers in Logistics Education, International Journal of Physical Distribution \& Logistics Management. DOI: http://dx.doi.org/10.1108/09600039810222756, 28(4): 302-319.

Roth, A. 2012. First and Further Education in Logistics [Ausund Weiterbildung in der Logistik]. In Klaus, P.; Krieger, W. (eds.). LogistikLexikon, 4. ed., Gabler, Wiesbaden, 27-34.

Roth, A. 2010. The German Logistics Education Market 2020 [Der Logistikbildungsmarkt 2020 - Bedarfsgerechte Bildungsangebote für die Logistikwirtschaft in der Logistik]. Habilitation RWTH, Aachen.

Roth, A.; Klaus, P. 2008. Education Market Logistics [Bildungsmarkt Logistik]. DVV, Hamburg.

Vastag, A.; Schaumann, H. 2012. Implementation Scenarios electric Mobility [Einsatzszenarien der Elektromobilität]. In Wolf-Kluthausen, H. (ed.): Jahrbuch Logistik 2012. Kersten, Berlin, 34-37.

Worldbank. 2014. Logistics Performance Index Global Ranking. Available from Internet: <http://lpi. worldbank.org/>. (adapted on 23.07.2014). 